\title{
Removal of Chromium by Biosorption Method (chitosan)
}

\author{
Yasabie Abatneh, Omprakash Sahu* \\ Department of Chemical Engineering, Kankeshwari Institute of Technology, \\ Jamnagar, Gujarat, India \\ Tel: +919752610958 \\ *E-mail address: ops0121@gmail.com
}

\begin{abstract}
Discharge of metal containing effluents into water has been a cause of major concern. Traditional treatment methods are proving to be ineffective and expensive. Chitosan was studied as a potential biosorbent due to its positive charge and relatively low cost. The study involves evaluating the metal binding performance of chitosan in a Polymer Enhanced Diafiltration (PEDF) system which uses an ultra filtration membrane to retain the chitosan which, in turn, binds the metal, thereby preventing passage into the permeate stream. Conditions for binding such as $\mathrm{pH}$, concentration of polymer and chromium were studied. Optimal performance was obtained when the system was operated at $\mathrm{pH}$ values lower than the $\mathrm{pKa}$ of chitosan i.e. 6.3. Using $6 \mathrm{~g} / \mathrm{L}$ chitosan at $\mathrm{pH} 4.0$, chromium concentration was reduced to less than $1 \mathrm{mg} / \mathrm{L}$ from a feed concentration of $20 \mathrm{mg} / \mathrm{L}$. Equilibrium dialysis experiments were done to study the kinetics of binding and the uptake of metal per gram of polymer. Rheological measurements demonstrated that in the presence of $1-100 \mathrm{mM}$ chromate, chitosan was found to be slightly shear thickening at low concentrations such as $4 \mathrm{~g} / \mathrm{L}$ and $6 \mathrm{~g} / \mathrm{L}$ whereas it was slightly shear thinning at higher concentrations like $12 \mathrm{~g} / \mathrm{L}$ and $20 \mathrm{~g} / \mathrm{L}$ This suggests that neutralization of chromium anions is due to the interaction of multiple chitosan molecules. This result is consistent with the relatively stiff nature of the polysaccharide. Overall, this study suggests that some modification of the native polymer would be required to improve uptake and make it an industrially workable process.
\end{abstract}

Keywords: Absorbent; Polymer; Natural; Water

\section{INTRODUCTION}

In the past century there has been a rapid expansion in the chemical industry. This has lead to an increase in the complexity of toxic effluents. Several industrial processes generate metal containing wastes. Heavy metal contamination has been a critical problem mainly because metals tend to persist and accumulate in the environment [1]. Chromium is one such toxic metal which is being widely used. Chromium is generated by electroplating, tanning and textile industry and is potentially toxic to humans [2]. Therefore the effluents being generated by these industries are rich in chromium. Textiles, electroplating, leather tanning and metallurgy industries extensively use chromium and therefore the wastes generated by these industries are rich in hexavalent or trivalent forms of chromium. Leakage, poor storage and improper disposal at the manufacturing and ore processing facilities have lead to release 
of chromium into the environment. This has lead to contamination of both ground and surface water [3].

The processes that are generally used for the removal of chromium are physical and chemical processes such as adsorption by activated carbon, reverse osmosis, reduction of hexavalent chromium into trivalent form and precipitation as chromium hydroxide. These treatments are expensive and not completely effective [4,5]. Chromium exists in oxidation states ranging from 0 to +6 . It occurs mainly in three forms. Metallic chromium $(\mathrm{Cr}[0])$ is a steel gray solid used to make steel and other alloys. This form does not occur naturally but is produced from chrome ore. In nature it exists in two oxidation states; $\mathrm{Cr}(\mathrm{III})$ and $\mathrm{Cr}(\mathrm{VI})$. $\mathrm{Cr}$ (III) occurs naturally in rocks, soils, plants and animals. Hexavalent chromium $\mathrm{Cr}(\mathrm{VI})$ is produced industrially when $\mathrm{Cr}(\mathrm{III})$ is heated in the presence of atmospheric oxygen. $\mathrm{Cr}(\mathrm{VI})$ is more toxic than $\mathrm{Cr}(\mathrm{III})$ and has therefore lead greater environmental concern [6,7]. Chromium(VI) exists in aqueous solutions as $\mathrm{Cr}_{2} \mathrm{O}_{7}{ }^{2-}, \mathrm{HCrO}_{4}{ }^{-}, \mathrm{CrO}_{4}{ }^{2-}$ and $\mathrm{HCr}_{2} \mathrm{O}_{7}{ }^{-}$[8]. The fraction of any particular species depends upon chromium concentration and $\mathrm{pH}[4,9]$. At neutral $\mathrm{pH} \mathrm{Cr}(\mathrm{VI})$ exists as $\mathrm{HCrO}_{4}{ }^{-}, \mathrm{CrO}_{4}{ }^{2-}$ and $\mathrm{H}_{2} \mathrm{CrO}_{4}{ }^{0}$. Under acidic conditions $\mathrm{HCrO}_{4}{ }^{-}$ polymerizes to form dichromate, $\mathrm{Cr}_{2} \mathrm{O}_{7}{ }^{2-}$. Chromate imparts a yellow color to water in concentrations above $1 \mathrm{mg} / \mathrm{L}$ [10] $\mathrm{Cr}$ (III) is an essential trace element in human nutrition. It is involved in glucose metabolism. Dietary deficiency of trivalent chromium has been associated with faulty sugar metabolism.

The required dietary amount has been reported from 50 to $200 \mu \mathrm{g}$ per day $[11,12]$. $\mathrm{Cr}(\mathrm{VI})$ can enter the body on breathing air, consuming food or water contaminated with it. Short term exposure due to inhalation at high levels can cause nosebleeds, ulcers, irritation of the nasal mucosa and holes in the nasal septum. Dermal exposure can also cause skin irritation and allergies [6]. Chromium is potentially toxic to humans as it is considered a carcinogen. It is also known to cause kidney failure, metabolic acidosis, and oral ulcers [13]. The U.S. Environmental Protection Agency (EPA) has set a Maximum Contaminant Level (MCL) in drinking water at $0.1 \mathrm{mg} / \mathrm{L}$ or $100 \mu \mathrm{g} / \mathrm{L}$. Soil concentrations are not strictly regulated by the EPA. There is an exposure risk among workers since it is used in many different industries. The Occupational Safety and Health Administration (OSHA) establish permissible exposure limits (PELs). The PEL for Cr (VI) in workplace air during a 40 hour work week is $100 \mu \mathrm{g} / \mathrm{m}^{3}$ [6].

Therefore there is a requirement for newer and effective methods which are also costeffective. Biosorption is a feasible option because it is both efficient and cheap. Compared with conventional methods for removing toxic metals from effluents, the biosorption process has the advantages of low operating cost, minimization of volume of chemicals and biological sludge to be disposed off and high efficiency in detoxifying very dilute effluents. Biosorption, which involves active and non-active uptake by biomass, is a good alternative to traditional processes. Widely available biopolymers are also being used for sorption mainly because they are a cheap resource [14]. Chitosan is obtained from the deacetylation of chitin. Chitin is one of the most abundantly available polymers after cellulose. Chitosan is a copolymer of glucosamine and $\mathrm{N}$-acetyl-glucosamine and it has an amine functional group which is strongly reactive with metal ions. Considerable research has been done on the uptake of metal cations by chitosan [15]. However, there are some metals which exist in aqueous solutions as anions, for example chromium.

The amine groups on chitosan bind metal cations at $\mathrm{pH}$ close to neutral. At low $\mathrm{pH}$, chitosan is more protonated; and therefore it is able to bind anions by electrostatic attraction [16]. Chitosan is chosen as the biosorbent because it is a cheaply available cationic polymer; a characteristic ideal for the binding of metal anions such as chromate. 
The aim of this study was demonstrating the use of chitosan as a biosorbent for uptake of chromate anions using polymer enhanced diafiltration (PEDF) system. The PEDF system uses an ultra filtration membrane that retains the polymer-metal complex and allows any unbound metal to pass through into the filtrate. The filtrate can be analyzed for the presence of chromium. The concentration of residual chromium will elucidate the binding ability of chitosan.

\section{MATERIAL AND METHODS}

Dynamic metals binding studies using chitosan in a polymer enhanced diafiltration system. This method was obtained from the work of Mark [17]. Chitosan was used as the biosorbent, the preparation of which is given below.

\section{1. Preparation of chitosan solution}

Chitosan (90\%) from DNP International (city and state) was used to make all chitosan solutions. Chitosan solutions from 2 to $20 \mathrm{~g} / \mathrm{L}$ were used for the experiments. The powdered chitosan was weighed and dissolved in $0.05 \mathrm{M}$ or $0.01 \mathrm{M}$ acetic acid, depending on the $\mathrm{pH}$ required. Slight adjustments in $\mathrm{pH}$ were made using $1 \mathrm{M}$ acetic acid.

\section{2. Preparation of chromium solution}

Analytical grade $\mathrm{K}_{2} \mathrm{Cr}_{2} \mathrm{O}_{7}$ (Mallinckrodt Chemicals Works, St. Louis, MO) was used to make all chromium standard solutions used in the experiments. A stock solution of 1000 $\mathrm{mg} / \mathrm{L}$ was prepared by dissolving the powder in reagent grade water. Working standards ranging from $10 \mathrm{mg} / \mathrm{L}$ to $100 \mathrm{mg} / \mathrm{L}$ were then prepared by appropriately diluting the stock solution. The $\mathrm{pH}$ of the metal solution was adjusted to that required by the experiment using $1 \mathrm{M} \mathrm{HCl}$ and $1 \mathrm{M} \mathrm{NaOH}$.

\section{3. Polymer enhanced diafiltration set-up}

The set-up (Fig. 1) consisted of a glass feed tank or reservoir. $500 \mathrm{ml}$ of chitosan solution made in acetic acid was placed in the reservoir. A pump (Millipore pump with Cole Parmer pump head, Model no 7016-20) was used to feed the metal into the reservoir containing chitosan solution. Another pump (Millipore pump with Cole Parmer pump head, model 7015-21) was used to feed the metal-chitosan complex onto the ultra filtration membrane. The solution in the reservoir was constantly stirred using a Magnetic stir plate. The membrane used was a Pellicon cassette from Millipore (10,000 and 30,000 MW cutoff, V channel).

The tubing used was Master flex (Masterflex 06485-15 and 06485-16). There were pressure gauges at both inlet and outlet indicating feed and retentive pressure respectively. There was a hand valve to control the feed and retentive pressure. The cross flow rate was maintained at $240 \mathrm{ml} / \mathrm{min}$. 


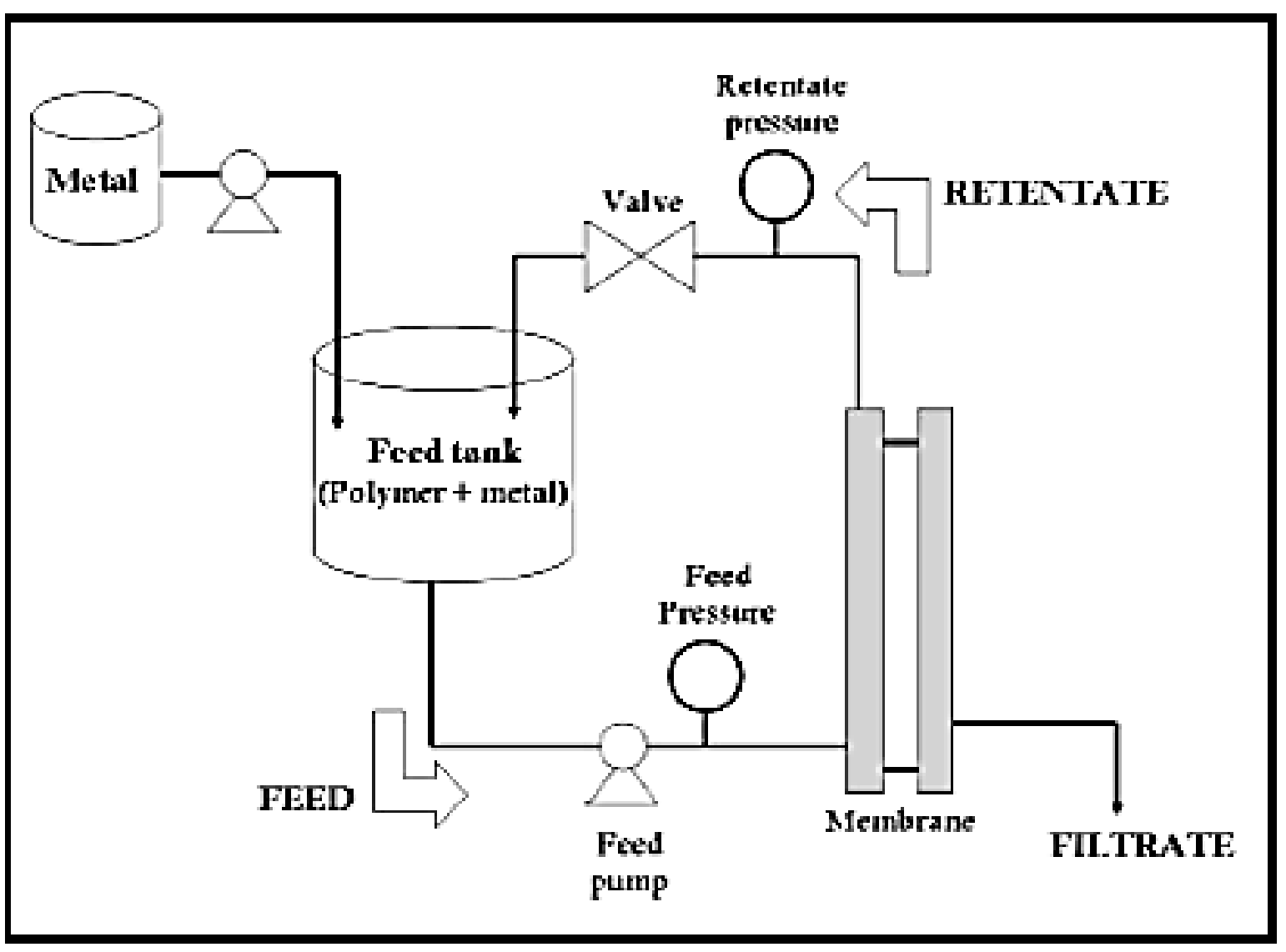

Fig. 1. Polymer Enhanced Diafiltration unit.

\section{4. PEDF operation}

A constant volume diafiltration was run. For this, the flow rate of the metal feed was maintained at the same rate that filtrate leaves the system. The transmembrane pressure was maintained throughout the run at 7-10 psi. The hand valve was used to maintain pressure during the run. Samples $(2 \mathrm{ml})$ of permeate were collected at regular intervals during the run and were analyzed for the presence of chromium using a spectrophotometric assay. The permeate flow rate in $\mathrm{mL} / \mathrm{min}$ was also measured at regular times. All systems were run at room temperature $\left(25^{\circ} \mathrm{C}\right)$. A control was run in the absence of chitosan in order to determine binding to the membrane. Instead of the polymer $0.05 \mathrm{M}$ acetic acid was used in the run.

\section{5. Determination of optimum concentration of chitosan using PEDF}

Different concentrations of chitosan were tested in PEDF. 2.0, 4.0, 5.0, 6.0 and $20.0 \mathrm{~g} / \mathrm{L}$ chitosan were used in separate runs. The starting feed concentration of the chromium in these runs was $20 \mathrm{mg} / \mathrm{L}$. The residual chromium in the permeate was estimated in each case in order to determine the binding by the polymer.

A $\mathrm{pH}$ probe was inserted in to the feed tank during the run such that $\mathrm{pH}$ could be maintained continuously. PH was maintained at 4.0 during each run using $1 \mathrm{M}$ acetic acid. Each run was performed at a transmembrane pressure of about 7 to $7.5 \mathrm{psi}$. The molecular weight cutoff of the membrane was $30 \mathrm{~K}$. The volume of permeate collected was measured and recorded throughout the run. 


\section{6. Buffer diafiltration to eliminate low molecular fractions}

PEDF was performed along with a buffer diafiltration in order to get rid of low molecular weight fractions of chitosan if any. This was done by adding $0.05 \mathrm{M}$ acetate buffer into the polymer containing reservoir for one hour. The PEDF was run circulating only buffer through the system without any addition of metal. After the buffer wash was done, metal solution $(20 \mathrm{mg} / \mathrm{L})$ was fed into the system. The PEDF was run at $4 \mathrm{~g} / \mathrm{L}$ chitosan at $\mathrm{pH}$ 4.0. Permeate samples were collected once the addition of metal was begun and estimated for residual chromium. Any changes in the permeate chromium concentrations were recorded in comparison with a run without buffer diafiltration. A $30 \mathrm{~K}$ MW cutoff membrane was used. Molecular weight fractions of chitosan if any. This was done by adding $0.05 \mathrm{M}$ acetate buffer into the polymer containing reservoir for one hour. The PEDF was run circulating only buffer through the system without any addition of metal. After the buffer wash was done, metal solution $(20 \mathrm{mg} / \mathrm{L})$ was fed into the system. The PEDF was run at $4 \mathrm{~g} / \mathrm{L}$ chitosan at $\mathrm{pH}$ 4.0. Permeate samples were collected once the addition of metal was begun and estimated for residual chromium. Any changes in the permeate chromium concentrations were recorded in comparison with a run without buffer diafiltration. A 30K MW cutoff membrane was used.

\section{7. Study of chromate binding properties of chitosan using Equilibrium dialysis (Construction of dialysis apparatus)}

This method was obtained from the study of [17]. The dialysis chambers are made of polycarbonate. Each dialysis apparatus consisting of two identical units were joined together with screws. Each unit consisted of 4 cells of $40 \mathrm{~mL}$ capacity each. When the units were joined together, the cell on each side was separated by a semi-permeable regenerated cellulose membrane (Spectra/Por dialysis pre-cut discs of $100 \mathrm{~mm}$ diameter obtained from Spectrum laboratories, MW cutoff $12-14 \mathrm{KDa}$ ) to give $80 \mathrm{~mL}$ chambers. Rubber O-rings were used around each cell to hold the membrane in position. Rubber stoppers were used to close the opening on the top of the chamber during the experiment to prevent evaporation issues. Before the experiment the dialysis units, stoppers and O-rings are leached in $1 \mathrm{M} \mathrm{HCl}$ for 8 hours to remove any trace metals. They are then rinsed in distilled water for 8 hours and then air dried. The dialysis membranes were washed prior to use with the following protocol. The membranes cut to size were soaked for an hour in a mixture of $0.01 \mathrm{M}$ Sodium Bicarbonate and $0.001 \mathrm{M} \mathrm{Na}$ EDTA at $37^{\circ} \mathrm{C}$. After one hour, the solution was decanted and some more was added to be soaked for another 30 minutes at $37^{\circ} \mathrm{C}$. This was then washed off and the membranes were rinsed with distilled water. This was followed by three changes of distilled water for 30 minutes each at $37^{\circ} \mathrm{C}$. The membranes could be stored like this in the refrigerator until use.

\section{9. Determination of kinetics of binding using equilibrium dialysis}

Chitosan solution of $2 \mathrm{~g} / \mathrm{L}$ was prepared by dissolving chitosan in $0.05 \mathrm{M}$ acetic acid at $\mathrm{pH}$ 4.0. Chromium solutions were made using $1000 \mathrm{mg} / \mathrm{L}$ stock by diluting it to $100 \mathrm{mg} / \mathrm{L}$. The $\mathrm{pH}$ of this solution was adjusted to 4.0 using $1 \mathrm{M} \mathrm{HCl}$ and $1 \mathrm{M} \mathrm{NaOH}$. The chitosan solution $(40 \mathrm{~mL})$ is added to the cell on side of the dialysis membrane and $40 \mathrm{~mL}$ of metal solution was added to the cell on the other side. The entire dialysis unit was kept in a shaker at $250 \mathrm{rpm}$ at $25{ }^{\circ} \mathrm{C}$. Samples $(100 \mu \mathrm{L})$ were taken every 2 hours from the feed cell into which the metal was initially added. These samples were then estimated for chromium using diphenyl-carbazide method. This was continued until equilibrium was reached. 
A simultaneous control experiment was done in the absence of chitosan where $0.05 \mathrm{M}$ acetic acid was added to the recovery cell instead of chitosan. Kinetics studies were also done at $\mathrm{pH} 3.0$.

\section{10. Determination of optimum $\mathrm{pH}$ for uptake using equilibrium dialysis}

The effect of $\mathrm{pH}$ on uptake was studied by studying binding at pH's 2.0, 3.0, 4.0 and 5.0. Chitosan solutions were prepared by mixing chitosan in acetate solutions at $\mathrm{pH} 2.0,3.0$, 4.0 and 5.0. $100 \mathrm{mg} / \mathrm{L}$ chromium working solution was prepared and $\mathrm{pH}$ was accordingly adjusted from 2.0-5.0 using $1 \mathrm{M} \mathrm{HCl}$ and $1 \mathrm{M} \mathrm{NaOH}$. $40 \mathrm{ml}$ of chitosan solution was added to the cell on one side and $40 \mathrm{ml}$ of chromium solution was added on the other side. The solutions on either side of the membrane were at the same $\mathrm{pH}$. Samples were taken initially to determine the initial metal concentration. The dialysis unit was kept under shaking conditions at $250 \mathrm{rpm}$ at $25^{\circ} \mathrm{C}$. Equilibrium was allowed to be established and samples $(100 \mu \mathrm{L})$ were taken after 24 hours to estimate the residual chromium using diphenyl-carbazide.

\section{11. Study of Equilibrium isotherm}

For the study of equilibrium isotherms, the dialysis was done at varying concentrations of the metal i.e. $10,30,50,60,80,100$ and $120 \mathrm{mg} / \mathrm{L}$ chromium. Chitosan used was at 2.0 $\mathrm{g} / \mathrm{L}$ at $\mathrm{pH}$ 4.0. The metal solutions were also adjusted at $\mathrm{pH} 4.0$. Forty $\mathrm{ml}$ of metal solutions was added to the feed cell on one side and $40 \mathrm{ml}$ chitosan solution was added to the recovery cell on the other side. The unit was placed under shaking conditions at $250 \mathrm{rpm}$ at $25^{\circ} \mathrm{C}$. Samples $(100 \mu \mathrm{L})$ were taken from the feed cell into which metal was added and estimated for chromium using diphenyl-carbazide. A control run was performed in the absence of chitosan, using $0.05 \mathrm{M}$ acetic acid in the recovery cell. $30 \mathrm{mg} / \mathrm{L}$ chromium was used in the feed cell of the control chamber. This would help determine if there was any binding to the membrane. After the final chromium concentrations were estimated the equilibrium isotherm was prepared by plotting uptake in $\mathrm{mg} / \mathrm{g}$ versus the equilibrium concentration of chromium in $\mathrm{mg} / \mathrm{L}$.

\section{RESULT AND DISCUSSION}

\section{1. Kinetics data analysis}

From the Fig. 2 it was observed that the time course of decrease in chromium concentration in the feed cell during an equilibrium dialysis at $\mathrm{pH}$ 3.0. In the absence of any chitosan, starting with a concentration of $115.2 \mathrm{mg} / \mathrm{L}$ of chromium, an equilibrium concentration of $55.8 \mathrm{mg} / \mathrm{L}$ is reached after 12 hours of dialysis. In the presence of $2 \mathrm{~g} / \mathrm{L}$ chitosan in the recovery cell, starting with a concentration of $115.2 \mathrm{mg} / \mathrm{L}$ of chromium, an equilibrium concentration of $16.2 \mathrm{mg} / \mathrm{L}$ is obtained after 12 hours. A reaction time of 10-12 hours is required to reach equilibrium.

From the Fig. 3 shows the time course of decrease in chromium concentration in the feed cell during an equilibrium dialysis at $\mathrm{pH}$ 4.0. In the absence of any chitosan, starting with a concentration of $126 \mathrm{mg} / \mathrm{L}$ of chromium, an equilibrium concentration of $60 \mathrm{mg} / \mathrm{L}$ is reached after 12 hours of dialysis. In the presence of $2 \mathrm{~g} / \mathrm{L}$ chitosan in the recovery cell, starting with a concentration of $126 \mathrm{mg} / \mathrm{L}$ of chromium, an equilibrium concentration of 14.2 $\mathrm{mg} / \mathrm{L}$ is obtained after 12 hours. From Figures 1 and 2, it can be seen that chitosan functions as a sorbent for chromate. This is evident from the decrease in free concentration of chromium in the presence of chitosan. 


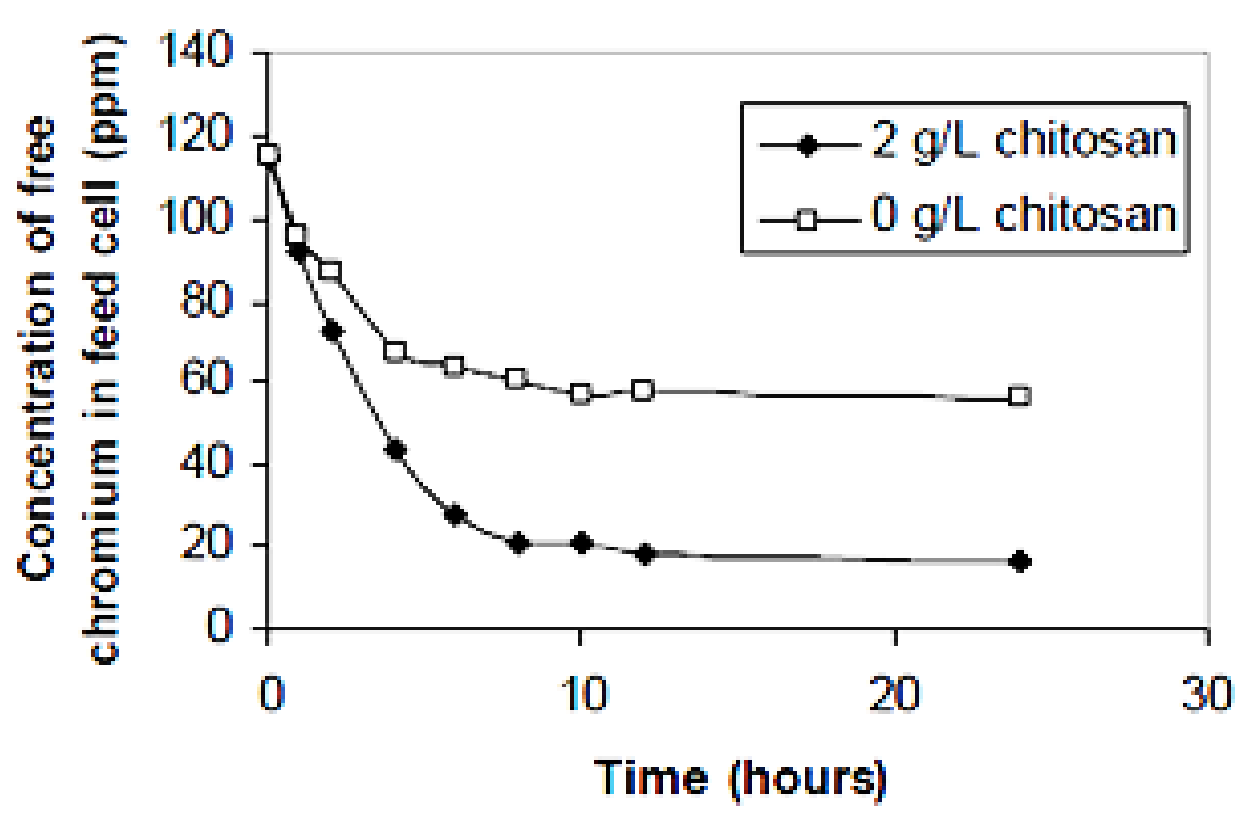

Figure 2. Kinetics of chromate uptake by chitosan at pH 3.0.

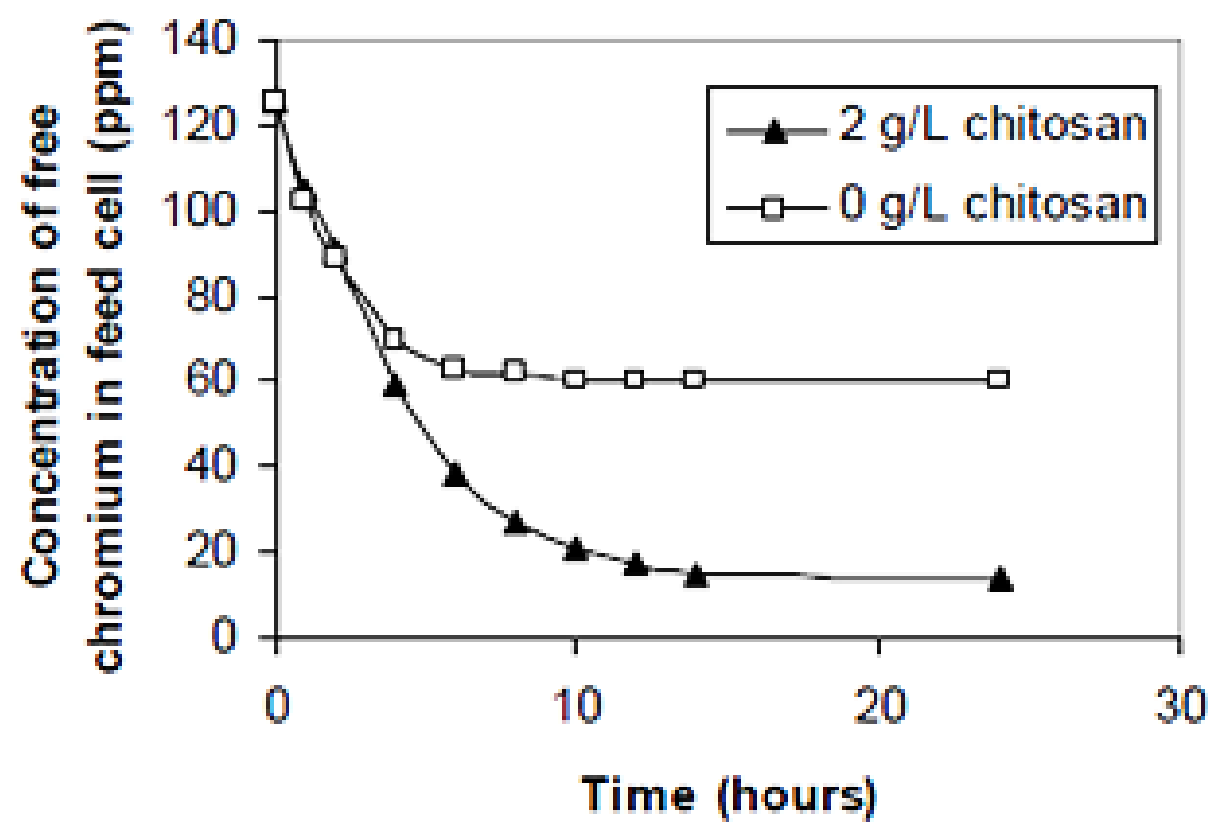

Figure 3. Kinetics of chromate uptake by chitosan at pH 4.0.

A reaction time of 10-12 hours is required to reach equilibrium. Based on this data an equilibrium time of 24 hours was allowed for all further equilibrium tests.

It was know that sorption kinetics is an important parameter to evaluate the basic qualities of a good sorbent. It helps us determine whether or not the sorbent adsorbs metals and to what extent. (Schmuhl et al, 2001). Removal of $\mathrm{Cr}(\mathrm{VI})$ at $\mathrm{pH} 3.0$ as a function of time 
is seen in Fig. 2 and 3 show the $\mathrm{Cr}(\mathrm{VI})$ removal with time at $\mathrm{pH} 4$. It can be seen that there is a decrease in the final free concentration of chromium when chitosan is present when compared to a 'no polymer' control. This indicates that fairly good binding of chromium occurs in the presence of chitosan. This also gives an indication of the time required by the metal-polymer reaction to reach equilibrium. A contact time of 10-12 hours is sufficient to reach equilibrium.

\section{2. Equilibrium Isotherm data analysis}

An equilibrium isotherm is a plot of uptake in $\mathrm{mg}$ of chromate/g of polymer. Figure 4 shows an equilibrium isotherm for chitosan at $\mathrm{pH}$ 4.0. The $\mathrm{Y}$ axis represents the equilibrium concentration of free chromium after 24 hours at $25^{\circ} \mathrm{C}$. Ideally, with increase in equilibrium free chromium concentration, uptake increases, until all the binding sites on the sorbent are saturated with no further increase in uptake. This represents $\mathrm{q}_{\max }$ or maximum adsorption capacity of the sorbent. As seen in Figure 4, $\mathrm{q}_{\max }$ could not be experimentally reached and no plateau in uptake was observed.

Therefore higher concentrations of chromium were tested as shown in Figure 5. At equilibrium concentrations as high as $350 \mathrm{mg} / \mathrm{L}$, there is still further increase in uptake. Therefore from Figures 4 and 5, we can deduce that the qmax is much higher than can be experimentally reached.

This might lead to estimating an asymptotic qmax from the KD value. Since the isotherm plot is non-linear, a reciprocal plot, which is linear, is used to calculate the $\mathrm{K}_{\mathrm{d}}$ and $\mathrm{q}_{\max }$ values from the experimental data. Figure 6 shows the linear reciprocal plot of 1/q versus 1/Ceq. The parameters KD and $\mathrm{q}_{\max }$ may be found by the following equation [18]:

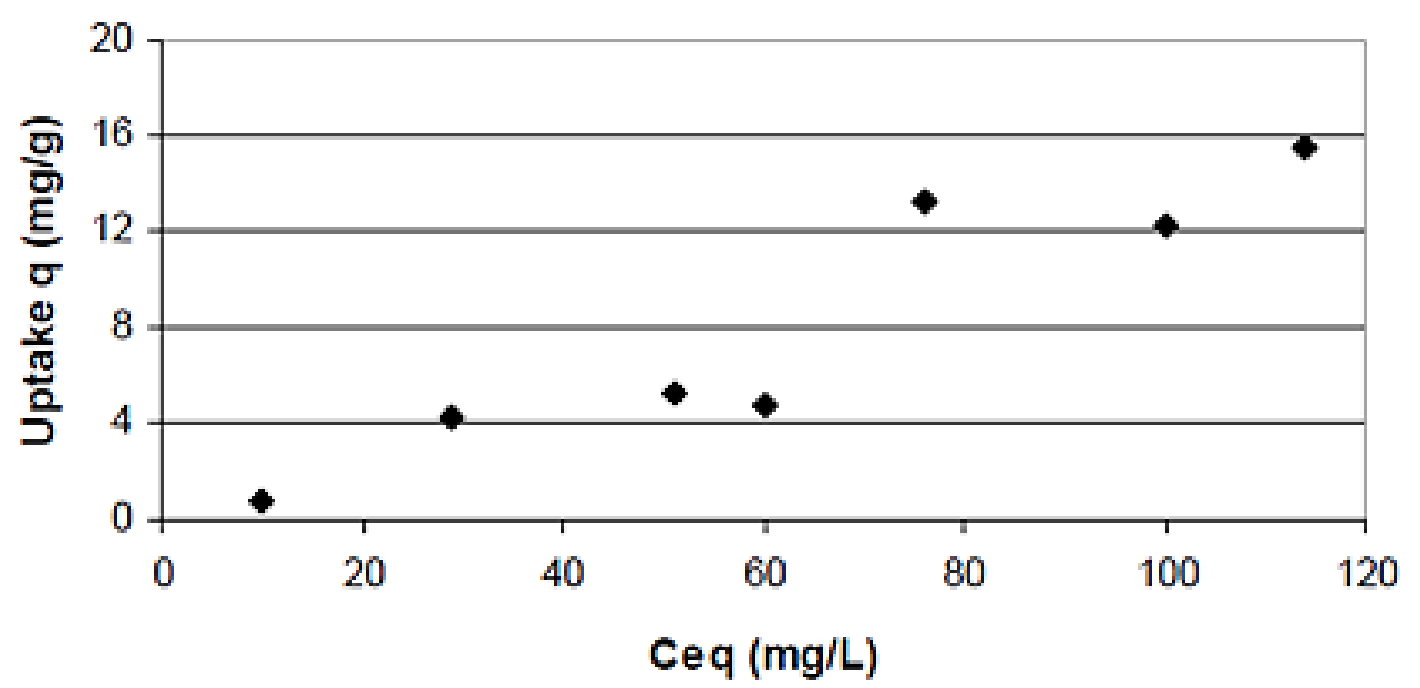

Figure 4. Equilibrium isotherm for adsorption of chromium by chitosan at $\mathrm{pH}$ 4.0.

From the slope and intercept of the straight line, the values of $\mathrm{q}_{\max }$ and $\mathrm{KD}$ can be found. The predicted line in Figure 6 is estimated by linear regression analysis by MS Excel from the experimental data. Excel was also used to obtain the equation of the line. From the equation, the values of KD were found to be $153 \mathrm{mg} / \mathrm{L}$. 


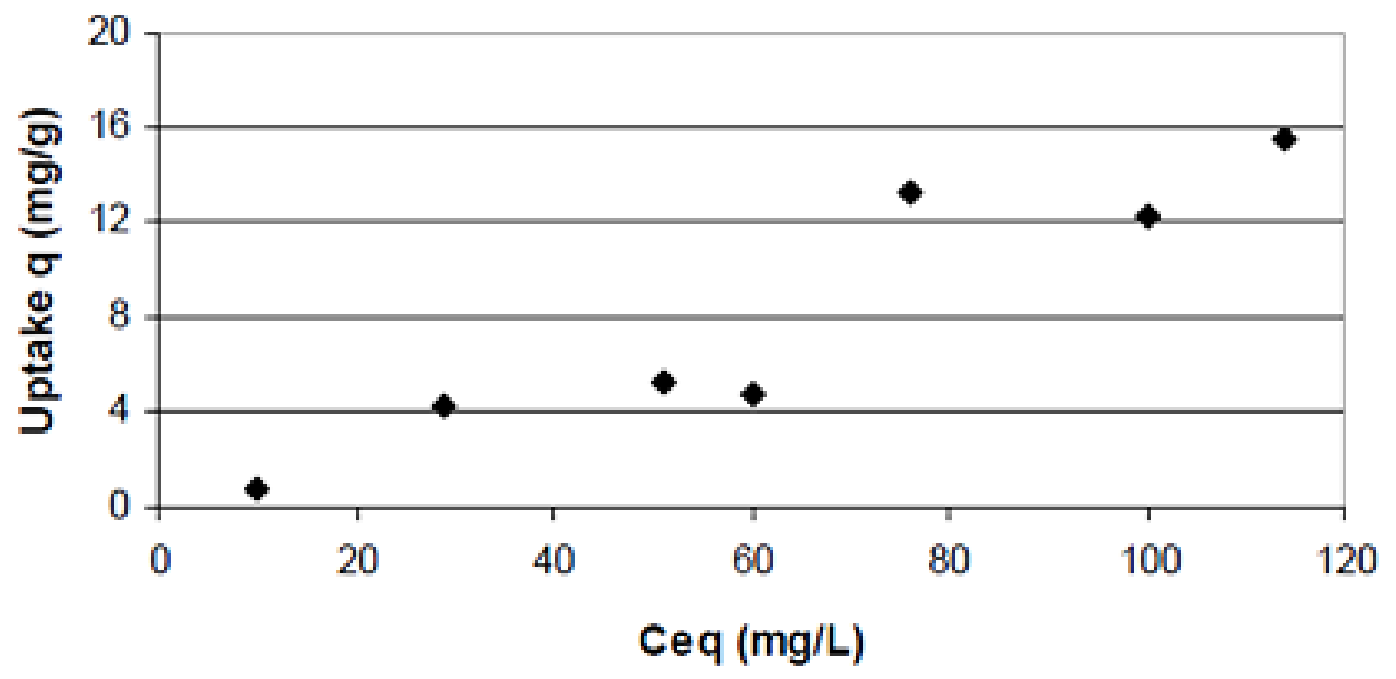

Figure 5. Equilibrium isotherm for adsorption of chromium at higher equilibrium concentrations.

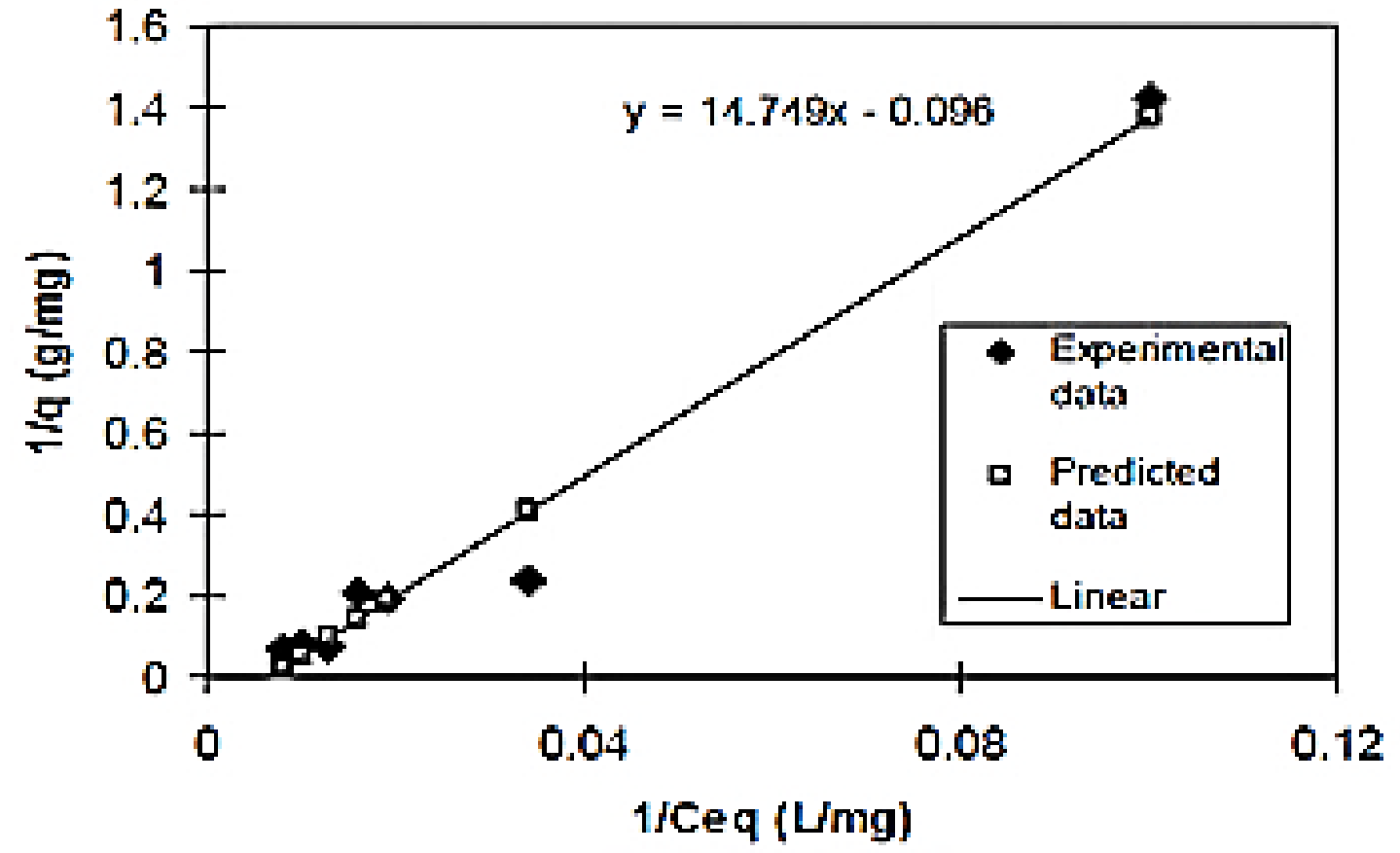

Figure 6. Reciprocal of the equilibrium isotherm plot.

$$
\frac{1}{q}=\frac{1}{q_{\max } K_{D} C_{e q}}+\frac{1}{q_{\max }}
$$

In a sorbent-sorbate system, sorption results in removal of the metal from the bulk solution as it gets adsorbed onto binding sites on the sorbent. This leads to a decrease in free chromium solution and an increase in chromium adsorbed on the sorbent, until equilibrium is 
reached between the uptake of chromium by chitosan and the equilibrium concentration of chromium in solution. At this equilibrium there is a defined distribution of the metal between the solid and liquid phases. This can be expressed by an isotherm. Figures 4 and Figure 5 represent these isotherms for chromium and chitosan. Unlike, most isotherms, these did not reach a plateau phase, in other words $\mathrm{q}_{\max }$ could not be experimentally reached. A reason for this could be that maximum adsorption for this sorbent-sorbate was higher than what could be experimentally determined. $\mathrm{q}_{\max }$ cannot be theoretically reached because it is an asymptotic limit.

Therefore from the equilibrium isotherm plot, a linear reciprocal plot was obtained. Using this linear plot and the Langmuir equation, the value for $\mathrm{K}_{\mathrm{D}}$ or dissociation constant was found to be $153 \mathrm{mg} / \mathrm{L}$. Since $\mathrm{q}_{\max }$ was too high and could not be experimentally determined, an estimate of $\mathrm{q}_{\max }$ was made based on the dissociation constant value. This estimated $\mathrm{q}_{\max }$ is about $300 \mathrm{mg} / \mathrm{g}$. Even though this is an estimated value, we can safely say that the uptake is definitely higher than $100 \mathrm{mg} / \mathrm{g}$ as can be seen from Figure 4, where at 350 $\mathrm{mg} / \mathrm{L}$ equilibrium concentration, the uptake is $110.5 \mathrm{mg} / \mathrm{g}$ and the plot is still linear. Other studies involving adsorption of chromium onto differently modified chitosan have shown the following adsorption capacities.

\section{3. Effect of pH on chromium uptake}

The method used here to estimate the optimum $\mathrm{pH}$ did not involve control of $\mathrm{pH}$ throughout the dialysis. The $\mathrm{pH}$ was adjusted initially and then tested again after the experiment. Table 1 shows the uptake in terms of $\mathrm{mg}$ chromium $/ \mathrm{g}$ of chitosan at the different $\mathrm{pH}$ tested. The $\mathrm{pH}$, before and after the dialysis experiment is also recorded. The optimum $\mathrm{pH}$ was found to be 4.0, followed by $\mathrm{pH}$ 3.0. All the subsequent experiments, including the Polymer Enhanced Diafiltration and the rheology studies, were performed at $\mathrm{pH} 4.0$ in accordance with this data. Experiments were carried out using $2 \mathrm{~g} / \mathrm{L}$ chitosan adjusted to different $\mathrm{pH} .100 \mathrm{mg} / \mathrm{L}$ chromium adjusted to the required $\mathrm{pH}$ was added to the feed cell. Uptake values are a mean of triplicates, temperature $25^{\circ} \mathrm{C}$.

Table 1. Effect of $\mathrm{pH}$ on uptake by equilibrium dialysis.

\begin{tabular}{cccc}
\hline S.No. & Intiail $\mathrm{pH}$ & Uptake $(\mathrm{mg} / \mathrm{g})$ & Finial $\mathrm{pH}$ \\
\hline 1 & 2.00 & 28.5 & 2.08 \\
2 & 3.00 & 32.4 & 3.09 \\
3 & 4.00 & 47.8 & 4.00 \\
4 & 5.00 & 43 & 5.12 \\
\hline
\end{tabular}

From Table 1, it can be seen that $\mathrm{pH} 4$ gave best chromate uptake, followed by $\mathrm{pH} 3$. The effect of $\mathrm{pH}$ on uptake can be explained on the basis of $\mathrm{pKa}$ of the amine groups of chitosan, which are 6.3. [9]. Below the pKa value of chitosan, the sorbent is positively charged, while the chromium anions in solutions are negatively charged. This leads to an electrostatic attraction between the two. Above the $\mathrm{pKa}$, the chitosan will be less protonated or neutral and hence $\mathrm{Cr}(\mathrm{VI})$ removal is reduced at $\mathrm{pH}$ higher than the $\mathrm{pKa}$. 


\section{CONCLUSION}

Chitosan is a good candidate for biosorption of chromium. Fairly high binding of chromate occurs as seen in the Polymer Enhanced Diafiltration (PEDF) runs. A higher concentration of chitosan gave a better uptake. Less than $1 \mathrm{mg} / \mathrm{L}$ chromium passed into the permeate when $6 \mathrm{~g} / \mathrm{L}$ chitosan was used. However, high concentrations, such as $20 \mathrm{~g} / \mathrm{L}$, led to reduction in permeate flux. It is, therefore, necessary to choose an optimum chitosan concentration without affecting the permeate flux. Higher concentrations mean high viscosities, thereby causing concentration polarization and affecting membrane performance. PEDF is a good process to concentrate metals from dilute aqueous solutions. It was also seen that chromium in the permeate is unbound chromium as there is no chitosan detected in the permeate. $\mathrm{PH}$ is an important parameter for uptake. Best uptake occurred at $\mathrm{pH} 4$ which is lower than the $\mathrm{pKa}$ of chitosan i.e. 6.3. At low $\mathrm{pH}$ chitosan has a greater number of protonated amine groups for binding. $\mathrm{PH}$ affects the speciation of the metal ion as well as the solubility of the polymer, which is important for a process like PEDF. The rheological studies helped to characterize the chitosan chromate interaction. The shear thickening behavior at low chitosan concentrations suggests that neutralization of chromate at low chitosan concentration is due to interaction of amine groups from multiple chitosan molecules. This behavior is not observed at high chitosan concentration. Future work in this area would involve the study of regeneration of the polymer, recovery of chromium from the chitosanchromate complex and scale-up of the process for industrial applicability.

\section{Acknowledgements}

Author acknowledge to department of chemical engineering KIOT for funding and facilities.

\section{Reference}

[1] Forstner U. (1983). Metal pollution in the aquatic environment. 2nd edition. SpringerVerlag, New York.

[2] Saifuddin M. Nomanbhay, Kumaran Palanisamy, Electronic Journal of Biotechnology 8(1) (2005).

[3] Dantas T. N., Dantas Neto, A. A., Moura M. C. P., Barros Neto E. L., de Paiya Telemaco E., Langmuir 17 (2001) 4256-4260.

[4] Sag A., Aktay Y., Process Biochemistry 36 (2000) 157-173.

[5] Rojas G., Silva J., Flores J. A., Rodriguez A., Ly M., Maldonado H., Separation and Purification Technology 44 (2005) 31-36.

[6] Booker S. M., Pellerin C., Health Perspectives 108 (2000) 402-407.

[7] Armienta-Hernandez M. A., Rodriguez-Castillo R., Environmental Health Perspectives 103 (1995) 1-8.

[8] Lee M-Y., Hong K-J., Shin-Ya Y., Kajiuchi T., Journal of Applied Polymer Science 96 (2005) 44-50.

[9] Udaybhaskar P., Iyengar L., Prabhakar Rao A. V. S., Journal of Applied Polymer Science 39 (1990) 739-747. 
[10] Palmer C. D., Wittbrodt P. R., Environmental Health Perspectives 92 (1991) 25-40.

[11] Katz S. A., Environmental Health Perspectives 92 (1991) 13-16.

[12] Shupack S. I., Environmental Health Perspectives 92 (1991) 7-11.

[13] EPA, 2000, Risk Characterization Handbook, Science Policy Council, U.S. Environmental Protection Agency, Washington, DC 20460.

[14] Niu H., Volesky B. Hydrometallurgy 71 (2003) 209-215.

[15] Rhazi M., Desbrières J., Tolaimate A., Rinaudo M., Vottero P., Alagui A., Polymer 43(77) (20002) 1267-1276.

[16] Guibal E., Separation and Purification Technology 38 (2004) 43-74.

[17] Mark S. S., Crusberg T. C., DaCunha C. M., Di Iorio A. A. Biotechnological Progress 22 (2006) 523-531. 